\title{
Recent advances in the management of malignant
}

\section{pheochromocytoma and paraganglioma: focus on tyrosine}

\section{kinase and hypoxia-inducible factor inhibitors [version 1; peer}

\section{review: 3 approved]}

\author{
Rodrigo Toledo¹, Camilo Jimenez (iD2 \\ ${ }^{1}$ Gastrointestinal and Endocrine Tumours Group, Vall d'Hebron Institute of Oncology, Barcelona, Spain \\ 2Department of Endocrine Neoplasia and Hormonal Disorders, The University of Texas MD Anderson Cancer Center, Houston, \\ Texas, USA
}

\section{V1 First published: 30 Jul 2018, 7(F1000 Faculty Rev):1148 \\ https://doi.org/10.12688/f1000research.13995.1 \\ Latest published: 30 Jul 2018, 7(F1000 Faculty Rev):1148 \\ https://doi.org/10.12688/f1000research.13995.1}

\begin{abstract}
Inactivating mutations of the succinate dehydrogenase subunit B ( $S D H B$ ) gene and the subsequent stabilization and activation of the hypoxia-inducible factor 2-alpha (HIF2a) unit are recognized hallmarks associated with the development of metastatic pheochromocytomas and paragangliomas (MPPG). Despite this discovery, the development of systemic therapies for patients with MPPG has been very slow. The rarity of the disease, the lack of preclinical animal models, and the impracticable development of large clinical trials has hindered the therapeutic progress for MPPG. Chemotherapy and low-specific activity ${ }^{131}$ meta-iodo-benzyl-guanidine (MIBG) (manufactured by simple isotope exchange methodology) led to positive clinical responses in about a third of patients. Molecular targeted therapies were introduced into oncological clinical practice at the beginning of the 21 st century. These therapies have been demonstrated to be effective for patients with cancers that previously exhibited limited responses to systemic chemotherapy, such as kidney and thyroid carcinomas and pancreatic neuroendocrine tumors. The pathogenesis of MPPG overlaps in some way with the pathogenesis of kidney, medullary thyroid, and pancreatic neuroendocrine carcinomas, providing scientific support to explore molecular targeted therapies such as tyrosine kinase and HIF inhibitors.
\end{abstract}

\section{Keywords}

Metastatic Pheochromocytoma, Metastatic paraganglioma, tyrosine kinase inhibitors, HIF inhibitors

\section{Open Peer Review}

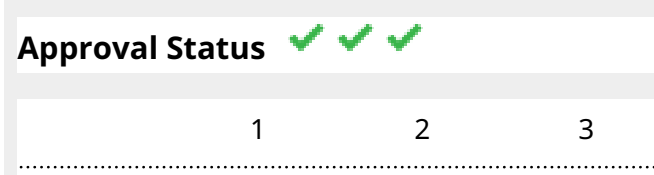

version 1

30 Jul 2018

Faculty Reviews are review articles written by the prestigious Members of Faculty Opinions. The articles are commissioned and peer reviewed before publication to ensure that the final, published version is comprehensive and accessible. The reviewers who approved the final version are listed with their names and affiliations.

1. Judith Favier, Paris-Centre de Recherche Cardiovasculaire, Paris, France

2. Carmen C. Solórzano, Vanderbilt University Medical Center, Nashville, USA

3. David Taïeb, La Timone University Hospital, Marseille, France

Aix-Marseille University, Marseille, France Any comments on the article can be found at the 
end of the article.

Corresponding author: Camilo Jimenez (cjimenez@mdanderson.org)

Author roles: Toledo R: Conceptualization, Data Curation, Formal Analysis, Funding Acquisition, Investigation, Methodology, Project Administration, Resources, Validation, Visualization, Writing - Original Draft Preparation, Writing - Review \& Editing; Jimenez C:

Conceptualization, Data Curation, Formal Analysis, Funding Acquisition, Investigation, Methodology, Project Administration, Resources, Software, Supervision, Validation, Visualization, Writing - Original Draft Preparation, Writing - Review \& Editing

Competing interests: No competing interests were disclosed.

Grant information: Rodrigo Toledo is a Miguel Servet-I Investigator (Institute of Health Carlos III) and is supported by a Fundación Olga Torres Emergent Researcher Grant. Rodrigo Toledo and Camilo Jimenez have received financial research support by a Paradifference Foundation Research Grant.

The funders had no role in study design, data collection and analysis, decision to publish, or preparation of the manuscript.

Copyright: ( $\subset 2018$ Toledo $\mathrm{R}$ and Jimenez $\mathrm{C}$. This is an open access article distributed under the terms of the Creative Commons Attribution License, which permits unrestricted use, distribution, and reproduction in any medium, provided the original work is properly cited.

How to cite this article: Toledo R and Jimenez C. Recent advances in the management of malignant pheochromocytoma and paraganglioma: focus on tyrosine kinase and hypoxia-inducible factor inhibitors [version 1; peer review: 3 approved] F1000Research 2018, 7(F1000 Faculty Rev):1148 https://doi.org/10.12688/f1000research.13995.1

First published: 30 Jul 2018, 7(F1000 Faculty Rev):1148 https://doi.org/10.12688/f1000research.13995.1 


\section{Introduction}

Pheochromocytomas and paragangliomas (PPG) are rare neuroendocrine tumors originating in the paraganglia. Pheochromocytomas originate in the adrenal medulla, and paragangliomas originate in the extra-adrenal paraganglia. Most of these tumors secrete excessive amounts of catecholamines that predispose patients to cardiovascular and gastrointestinal morbidity ${ }^{1,2}$. About $15 \%$ to $20 \%$ of these tumors are metastatic, leading to a decreased overall survival ${ }^{3}$. There are no histological, genetic, or molecular markers that could distinguish between benign and malignant disease and subsequently the diagnosis of malignancy relies exclusively on the presence of metastases ${ }^{4}$; unfortunately, by then, the disease is usually advanced ${ }^{5}$. In fact, only $50 \%$ to $60 \%$ of patients with metastatic pheochromocytomas and paragangliomas (MPPG) are still alive 5 years after the discovery of metastases ${ }^{6}$. Metastases usually involve the lymph nodes $(80 \%)$, the skeletal tissue $(71 \%)$, the liver $(50 \%)$, and the lungs $(50 \%)^{7}$. Whereas some patients succumb to the metastatic tumor burden, others may die because of complications derived from the excessive secretion of catecholamines ${ }^{8}$. Currently, there are no systemic therapies approved by the European Medicines Agency or the US Food and Drug Administration (FDA) for patients with MPPG. Treatment options are limited to chemotherapy and low-specific activity ${ }^{131}$ meta-iodo-benzyl-guanidine (MIBG) and usually fail to produce a prolonged remission ${ }^{9,10}$. Furthermore, toxicity associated with chemotherapy and radiopharmaceutical agents cannot be underestimated $^{11}$. This scenario illustrates that the identification of clinically effective medications to treatMPPG is perhaps the most important unmet clinical need.

\section{Molecular pathogenesis of MPPG}

The molecular pathogenesis of a substantial number of MPPG was elucidated in the early 2000s, when germline mutations of the succinate dehydrogenase subunit $\mathrm{B}(S D H B)$ gene were identified $^{12,13}$. Since then, the link between $S D H B$ loss and increased risk for MPPG has been validated by several independent studies. It has been determined that about $30 \%$ to $40 \%$ of patients with MPPG carry a germline mutation of the $S D H B$ gene $^{14,15}$. These mutations prevent the oxidative catabolism of succinate to fumarate and electron transportation through the internal mitochondrial membrane. Consequently, accumulation of succinate acts as an oncometabolite, leading to stabilization and activation of hypoxia-inducible factors (HIFs), mainly the HIF2alpha $(\mathrm{HIF} 2 \alpha)$ unit $^{16,17}$. Increased expression of HIF2 $\alpha$-targeted genes such as the vascular endothelial growth factors (VEGFs) and the platelet-derived growth factor beta (PDGF- $\beta$ ) and their receptors is observed in $S D H B$ MPPG as well as many apparently sporadic tumors ${ }^{18}$. In addition, genes involved in glucose metabolism, such as the hexokinase 2 and lactate dehydrogenase genes, are also upregulated ${ }^{18}$. Activation of all of these genes leads to abnormally increased angiogenesis and cell growth, decreased apoptosis, and increased glucose uptake ${ }^{19}$.

\section{Challenges in the discovery of new medications to treat MPPG}

Although the genetic causes of many MPPG (mainly SDHB mutations) and the molecular events leading to the metastatic transformation of chromaffin cells (stabilization and activation of HIF2 $\alpha$, DNA hypermethylation) ${ }^{20}$ were determined several years ago, the development of therapeutics against MPPG has been very slow for three main reasons: (a) difficulty of patient enrollment in large clinical trials, (b) lack of preclinical animal models, and (c) lack of efficient, targeted drugs. Given the rarity of MPPG (estimated incidence is less than one per million people per year), it is almost impossible to have multiple clinical trials testing a variety of drugs or drug combinations concomitantly. Several knockout mouse models for SDHB and other pheochromocytoma- and paraganglioma-related genes leading to activation of HIF $2 \alpha$ (that is, von Hippel-Lindau and the mitochondrial enzymatic complex II subunit D genes) have not been demonstrated to mimic the human phenotype ${ }^{21,22}$. The lack of a reliable preclinical animal model is a major drawback that has impaired the screening of available drugs and drug combinations. Subsequently, the design of effective clinical trials relies mainly on clinical observations and increases the risk of wasting time and effort on trials that yield little or no benefit for patients with $\mathrm{MPPG}^{23,24}$. Moreover, the lack of animal models makes it very difficult to identify mechanisms of resistance that would enable the design of trials that combine therapies that could concomitantly or sequentially tackle escape pathways, prolonging clinical benefits. Therefore, clinical scientists and pharmaceutical research have prioritized their efforts on the few most promising medications to ensure sufficient patient enrollment. These difficulties have resulted in very slow progress and circumscribed therapeutic improvements.

\section{Tyrosine kinase inhibitors under evaluation in clinical trials}

Several tyrosine kinase inhibitors (TKIs), including axitinib, cabozantinib, lenvatinib, pazopanib, and sunitinib, are currently under evaluation in phase II clinical trials (www.ClinicalTrials.gov). These agents have in common their capacity to block the activation of the VEGF receptors (VEGFRs), preventing angiogenesis and cell growth ${ }^{25}$ (Figure 1). In addition, TKIs can inhibit other tyrosine kinase receptors that are universally involved in processes such as cancer cell growth, tumor spread, and development of resistance ${ }^{26,27}$ (Figure 1). Compelling positive results derived from phase III clinical trials have led to their approval by regulatory agencies for the treatment of malignancies such as kidney, thyroid, and pancreatic neuroendocrine carcinomas. Of interest, the pathogenesis of these tumors frequently overlaps with the pathogenesis of MPPG, supporting the development of clinical trials for MPPG. A historical description of preliminary clinical findings in MPPG treated with these medications follows.

\section{Sunitinib}

Sunitinib was the first TKI described as a possibly effective treatment for patients with MPPG. Sunitinib was approved for the treatment of advanced kidney cancer on the basis of the impressive results derived from a phase III clinical trial ${ }^{28}$. In 2008, two simultaneous case reports described potential benefits derived from sunitinib. In a patient with MPPG in the context of von Hippel-Lindau disease, sunitinib was associated with tumor size reduction and blood pressure and pain control. 


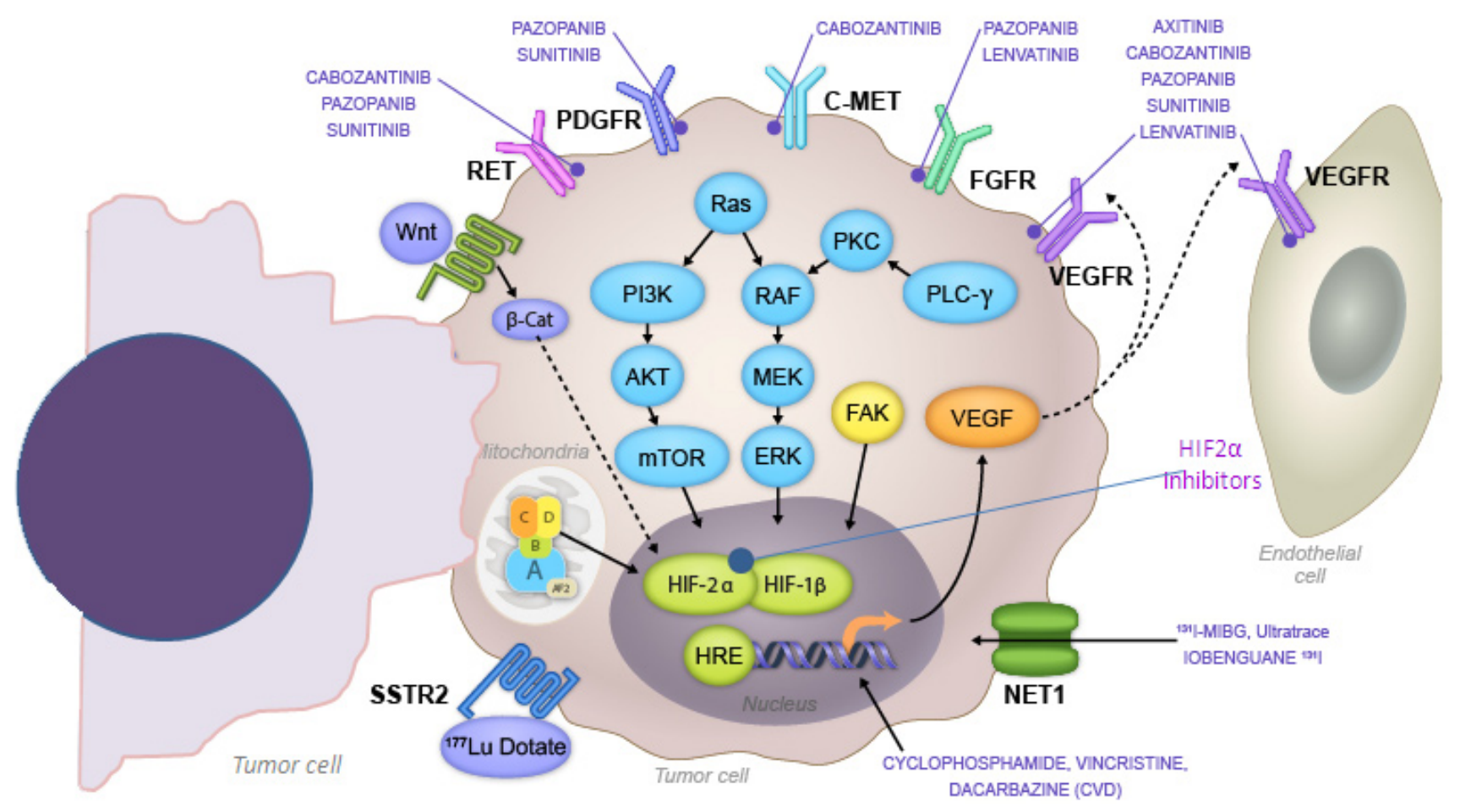

Figure 1. Pharmacodynamics of tyrosine kinase and hypoxia-inducible factor $2 \alpha$ inhibitors under evaluation in clinical trials for patients with metastatic pheochromocytomas and paragangliomas. This figure includes information on the mechanism of action of systemic chemotherapy and radiopharmaceutical agents: ${ }^{131}$ meta-iodo-benzyl-guanidine (MIBG) and ${ }^{177}$ Lu-DOTATATE.

The decision to study sunitinib in this patient was supported by the demonstration of a very high expression of VEGF and PDGFRB-1 in the removed primary tumor and the simultaneous presentation of progressive multifocal kidney cancer for which sunitinib was indicated ${ }^{29}$. In another case report, the discovery of benefits derived from sunitinib was accidental. The patient presented with a large unresectable mass suspicious of kidney cancer; the patient received sunitinib and the tumor became resectable. Surprisingly, histological evaluation confirmed a paraganglioma ${ }^{30}$. Over time, several MPPG patients who were not candidates or responsive to chemotherapy/MIBG received sunitinib. In a retrospective intention-to-treat analysis of 17 patients who received sunitinib, $47 \%$ exhibited partial responses and disease stabilization with blood pressure control despite catecholamine excess. Positive responses were noticed in carriers of $S D H B$ mutations as well as patients with apparently sporadic tumors. Progression-free survival was only 4.1 months; $23.5 \%$ of patients discontinued therapy because of adverse events such as overwhelming fatigue, pain exacerbation, hand and foot syndrome, and cardiovascular disease (severe hypertension and syncope $)^{31}$. Two phase II clinical trials with sunitinib are ongoing (www.ClinicalTrials.gov).

\section{Pazopanib}

The mechanism of action of pazopanib overlaps with that of sunitinib; like sunitinib, pazopanib is approved for the treatment of patients with kidney cancer. Some studies in kidney cancer previously suggested that pazopanib could be an easier medication to tolerate than sunitinib ${ }^{32,33}$. A phase II clinical trial for MPPG with pazopanib was subsequently developed. The primary endpoint of the trial was best objective response rate. Intervention was pazopanib $400 \mathrm{mg}$ daily for 2 weeks followed by dose titration to $800 \mathrm{mg}$ daily. The trial recruited seven patients. Only one patient exhibited a confirmed partial response that lasted for about 2 years. Several patients had overwhelming side effects: $17 \%$ had grade 3-4 diarrhea, hematuria, headaches, and fatigue, and $50 \%$ had severe hypertension ${ }^{34}$. Toxicity was more obvious after doubling the dose of pazopanib. The trial was terminated because of lack of recruitment.

\section{Axitinib}

Axitinib is a pure anti-angiogenic medication. As it only blocks the VEGFR, it may be associated with fewer adverse events when compared with sunitinib and pazopanib ${ }^{35}$. Axitinib is also approved for the treatment of kidney cancer. However, experience with axitinib in patients with kidney cancer has demonstrated that hypertension might be a difficult problem to face during treatment ${ }^{36}$. A phase II clinical trial for MPPG was developed. The trial recruited 11 patients. The primary endpoint was objective response rate. Intervention was axitinib $5 \mathrm{mg}$ twice dose with dose titration to $7.5-10 \mathrm{mg}$ twice a day; $36 \%$ of patients achieved a partial response. Severe hypertension was noticed in 
$82 \%$ of patients and dose could not be titrated up. Conversely, all patients required dose reduction ${ }^{37}$. The trial is currently closed for recruitment.

\section{Cabozantinib}

Cabozantinib is perhaps the most potent anti-angiogenic medication currently approved for the treatment of cancer ${ }^{38}$. In addition to inhibiting the VEGFRs, cabozantinib inhibits the c-met receptor pathways which are involved in tumor growth and spread and the development of resistance to anti-angiogenesis ${ }^{38}$. Cabozantinib is approved for the treatment of medullary thyroid and kidney cancers ${ }^{39,40}$ and seems to be more effective than sunitinib in advanced kidney cancer ${ }^{41}$. A phase II clinical trial with cabozantinib is ongoing. The trial is expected to recruit 22 patients. The primary endpoint is objective response rate. Intervention is cabozantinib $60 \mathrm{mg}$ daily. Unlike the previously described clinical trials, the trial with cabozantinib allows dose titration down to 40 and $20 \mathrm{mg}$, as clinical observations in patients with other cancers have demonstrated positive responses despite the dose reduction. Preliminary results derived from 14 patients who received cabozantinib reveal that $93 \%$ of them have exhibited partial responses or disease stabilization with some degree of regression ${ }^{42}$. To date, the clinical trial has not reported grade 4 or 5 adverse events. Two patients presented with grade 3 adverse events; these events were an asymptomatic elevation of pancreatic enzymes and a rectal fistula that was corrected with surgery. Hypertension, mainly grade 1 , has been noticed in $40 \%$ of patients ${ }^{42}$. The trial includes an exploratory branch for patients with predominant bone metastases. The trial is actively recruiting patients.

\section{Lenvatinib}

Lenvatinib is another potent anti-angiogenic medication. It also inhibits the fibroblast growth factor receptor pathway. Lenvatinib is approved for the treatment of advanced thyroid cancer of follicular origin ${ }^{43}$ and has demonstrated clinical effectiveness in medullary thyroid cancer ${ }^{44}$. Lenvatinib in combination with everolimus is also approved for the treatment of kidney cancer ${ }^{45}$. Isolated clinical experience suggested that this medication may have a positive impact on MPPG. A phase II clinical trial with lenvatinib is looking at objective response rate as the primary endpoint. This trial recently initiated recruitment (www.ClinicalTrials.gov).

\section{Tyrosine kinase inhibitors and cardiovascular events in patients with MPPG}

Preliminary results of several clinical trials show that several TKIs with mainly anti-angiogenic activity may cause anti-tumor effects in a substantial number of patients with $\mathrm{MPPG}^{31,34}$. However, effectiveness has been undermined by cardiovascular events $^{34}$. It is important to recognize that MPPG are indeed more difficult to treat than other cancers given the endocrine nature of the disease. Most patients with MPPG are found with a large tumor burden ${ }^{3}$. Furthermore, the majority of these tumors secrete excessive amounts of catecholamines, mainly noradrenaline. Therefore, patients with MPPG have an elevated risk for severe cardiovascular disease upon exposure to systemic therapies such as TKIs. Hypertension and cardiovascular disease may be caused by a combination of medication, direct cardiovascular toxicity (that is, inhibition of nitric oxide synthesis) ${ }^{46}$, or the rapid and massive release of catecholamines once the tumor destruction starts. Guidelines on how to treat MPPG are not existent. Nevertheless, treatment with alpha- and beta-blockers should be offered to all patients with catecholamine-secreting $\mathrm{PPG}^{1,47}$. Alpha-blockers should be started first and titrated as soon as possible in order to achieve orthostatism and allow the initiation of the beta-blockers to protect the heart ${ }^{1}$. Alphaand beta-blockers could be titrated to very high doses (that is, doxazosin $16 \mathrm{mg}$ daily; propranolol $640 \mathrm{mg}$ daily ${ }^{48,49}$; nevertheless, concerns related to high-dose toxicity and lack of effectiveness have been raised. Therefore, patients frequently need the addition of other anti-hypertensive drugs such as calcium channel blockers, angiotensin-converting enzyme inhibitors, angiotensin receptor blockers, labetalol, hydralazine, or catecholamine synthesis inhibitors (metyrosine) or a combination of these ${ }^{50}$. In fact, studies have shown that patients with MPPG may need an average of four to six anti-hypertensive drugs in order to normalize their blood pressure. The clinical trials have shown that the doses of different TKIs must be carefully chosen. As suggested by the preliminary results of the cabozantinib phase II study, it is always better to choose a starting dose that is clearly associated with clinical benefits and that allows dose titration down, preserving effectiveness. This approach may allow one to later titrate the dose up once an anti-tumor effect is achieved, as catecholamine secretion may have already decreased by then. In the meantime, anti-hypertensive doses should be adjusted accordingly. Acute complications are not uncommon, and treating physicians and principal investigators must be familiar with the treatment of hypertensive crisis with medications such as nitroprusside, nicardipine, and esmolol. It is also important to remember that patients with MPPG may have easier-to-control blood pressure after primary tumor resection (if possible) because of a decreased catecholamine surge ${ }^{51}$. Surgery of the primary tumor and solitary metastasis should be considered before any systemic therapy is instituted.

\section{Tyrosine kinase inhibitors and other drug-related adverse events}

Patients who receive TKIs frequently complain of constitutional symptoms, hand and foot syndrome, pain exacerbation, and gastrointestinal irritability among other symptoms. Treating physicians must be familiar with these potential side effects and beforehand should establish therapeutic interventions that could prevent exacerbation of these symptoms to guarantee a successful treatment. These interventions may include-but are not limited to- the use of moisturizer lotions to prevent dryness, avoidance of overuse of hands and feet, and adjustment of analgesic doses before initiation of therapy to prevent pain exacerbation in patients with bone metastases. Constipation is an uncommon but sometimes difficult complication in patients with $\mathrm{MPPG}^{2}$. TKIs frequently cause diarrhea. Although this adverse event could benefit patients with constipation, our clinical experience indicates that it is better to treat the constipation with other interventions before a molecular targeted therapy is started. Symptoms such as nausea, vomiting, and abdominal pain could be severe in constipated patients who receive targeted 
therapies $^{52}$; these symptoms may prevent patients from taking systemic therapy.

Anti-angiogenic TKls inhibit part of the HIF2 $\alpha$ pathway As described above, treatment of MPPG with anti-angiogenic TKIs can lead to partial responses and stable disease; however, such treatments may have limited long-term benefits, since patients developed subsequent resistance and progression ${ }^{31}$. One plausible explanation for this is that while these drugs inhibit mainly the angiogenic pathway through VEGFRs, the observed progression and resistance may be related to the compensatory activation of HIF $2 \alpha$ molecular pathways caused by hypoxia induced by blood vessel regression ${ }^{53}$.

Robust molecular studies have identified HIF2 $\alpha$ as one of the main oncogenic drivers of paraganglioma/pheochromocytoma $(\text { PPGL })^{54,55}$. In addition to $S D H B$ mutations leading to HIF2 $\alpha$ activation, mutations in the HIF2 $\alpha$-encoding gene (EPASI) have been identified and functionally characterized in $\mathrm{PPGL}^{56}$. These validated findings, implicating the disruption of genes involved in the response to hypoxia, have spearheaded the initiation of therapeutic strategies to directly tackle HIF2 $\alpha$ (Figure 1).

\section{Development of first-in-class HIF2 $\alpha$ inhibitors}

For many years, transcription factors, including HIF2 $\alpha$, were considered undruggable, and pharmaceutical research focused mainly on the HIF pathway downstream (that is, VEGFR2). In 2009, the structure of a heterodimer between the HIF2 $\alpha$ PAS (Per-ARNT-Sim) domains-which sensor oxygen and REDOX potential-and ARNT was solved by crystallography, enabling the identification of a large protein cavity located within the HIF2 $\alpha$ PAS-B domain. Such a bulky cavity, which is extremely rare in proteins, was expected to accommodate small molecules and therefore to be successfully targeted. Based on the structure of the HIF2 $\alpha$ :ARNT protein dimer, an extensive screening of small-molecule libraries has been performed and identified specific HIF2 $\alpha$ inhibitors with potential for clinical development.

\section{HIF2 $\alpha$ inhibitors show low toxicity and high clinical efficiency in human hypoxic tumors}

HIF $2 \alpha$ inhibitors have shown tumor inhibition in both in vitro and in vivo models of clear cell renal cell carcinomas (RCCs) associated with pseudo-hypoxia ${ }^{57}$. The results of a clinical trial with a HIF2 $\alpha$ inhibitor in patients with locally advanced or metastatic RCC that progressed with at least one prior systemic therapy revealed complete responses, partial responses, and stable disease in $2 \%, 12 \%$, and $52 \%$ of heavily pretreated patients, respectively. Of interest, no patients discontinued treatment because of adverse events ${ }^{58}$. Further studies are required to determine whether such promising HIF $2 \alpha$ antagonists will be effective for the treatment of MPPG.

\section{Other molecular targeted therapies}

In addition to the tyrosine kinase and HIF $2 \alpha$ inhibitors, there are molecular targeted therapies that have or may have a positive impact in MPPG. These therapies include radiopharmaceutical medications such as high-specific activity MIBG and peptide receptor radionuclide therapy (PRRT). The final results of the phase II clinical trial with high-specific activity MIBG (Azedra ${ }^{\circledR}$ ) for MPPG that express the cell membrane catecholamineuptake transporter are impressive; more than $90 \%$ of patients exhibit clinical benefits ${ }^{59}$. This medication has received breakthrough therapy designation by the FDA, and the clinical results are currently under evaluation by this regulatory agency. PRRT was recently approved for the treatment of gastroenteropancreatic neuroendocrine tumors that express cell membrane somatostatin receptors ${ }^{60}$. MPPG frequently express somatostatin receptors in the cell membrane; subsequently, these patients may benefit from PRRT ${ }^{61}$. A phase II clinical trial with ${ }^{177}$ Lu-DOTATATE was recently activated (www.ClinicalTrials.gov). As the focus of this article is on tyrosine kinase and HIF2 $\alpha$ inhibitors, we will not discuss these therapies further.

\section{Conclusions}

Observations derived from phase II clinical trials with tyrosine kinase and HIF inhibitors have revealed anti-neoplastic effects. However, it is important to recognize that MPPG are more challenging to treat when compared with other oncological conditions that are also treated with these medications. Their large tumor burden and their frequently overwhelming hormonal manifestations may lead to a high rate of adverse events. Clinical trials must be carefully designed and should actively involve clinicians familiar with the endocrine manifestations of MPPG. Results of several clinical trials with TKIs are still preliminary, and we cannot yet define the therapeutic role that these medications might have in MPPG. HIF2 $\alpha$ inhibitors may target the core of the MPPG pathogenesis and, together with cabozantinib, are perhaps some of the most exciting medications to explore in MPPG. As expected, tyrosine kinase and HIF inhibitors could control but alone cannot cure advanced MPPG. Therefore, the research effort to understand the pathogenesis of MPPG must continue, as it is clearly helping to identify potential therapies. This effort will help us to recognize medications with unique and fundamental mechanisms of action that, when used alone or especially in combination, may finally help to conquer this orphan and devastating disease.

\section{Competing interests}

The authors declare that they have no competing interests.

\section{Grant information}

Rodrigo Toledo is a Miguel Servet-I Investigator (Institute of Health Carlos III) and is supported by a Fundación Olga Torres Emergent Researcher Grant. Rodrigo Toledo and Camilo Jimenez have received financial research support by a Paradifference Foundation Research Grant.

The funders had no role in study design, data collection and analysis, decision to publish, or preparation of the manuscript.

\section{Acknowledgments}

Camilo Jimenez would like to acknowledge Ms Natalie Papadam, Mr Peter Liu, the Team Nat Foundation, Ms Margaret Cazalot, Ms Marle Granek, and Dr Catherine Cotten for their immense support in developing clinical trials for patients with malignant pheochromocytomas and paragangliomas. 
1. F Lenders JW, Duh QY, Eisenhofer G, et al:: Pheochromocytoma and paraganglioma: an endocrine society clinical practice guideline. J Clin Endocrinol Metab. 2014; 99(6): 1915-42.

PubMed Abstract | Publisher Full Text | F1000 Recommendation

2. Thosani S, Ayala-Ramirez M, Román-González A, et al.: Constipation: an overlooked, unmanaged symptom of patients with pheochromocytoma and sympathetic paraganglioma. Eur J Endocrinol. 2015; 173(3): 377-87. PubMed Abstract | Publisher Full Text

3. Ayala-Ramirez M, Feng L, Johnson MM, et al.: Clinical risk factors for malignancy and overall survival in patients with pheochromocytomas and sympathetic paragangliomas: primary tumor size and primary tumor location as prognostic indicators. J Clin Endocrinol Metab. 2011; 96(3): 717-25. PubMed Abstract | Publisher Full Text

4. F Lam AK: Update on Adrenal Tumours in 2017 World Health Organization (WHO) of Endocrine Tumours. Endocr Pathol. 2017; 28(3): 213-27. PubMed Abstract | Publisher Full Text | F1000 Recommendation

5. F Roman-Gonzalez A, Jimenez C: Malignant pheochromocytomaparaganglioma: pathogenesis, TNM staging, and current clinical trials. Curr Opin Endocrinol Diabetes Obes. 2017; 24(3): 174-83. PubMed Abstract | Publisher Full Text | F1000 Recommendation

6. Jimenez C, Rohren E, Habra MA, et al.: Current and future treatments for malignant pheochromocytoma and sympathetic paraganglioma. Curr Oncol Rep. 2013; 15(4): 356-71.

PubMed Abstract | Publisher Full Text

7. Baudin E, Habra MA, Deschamps F, et al:: Therapy of endocrine disease: treatment of malignant pheochromocytoma and paraganglioma. Eur $J$ Endocrinol. 2014; 171(3): R111-22. PubMed Abstract | Publisher Full Text

8. Jimenez P, Tatsui C, Jessop A, et al: Treatment for Malignant Pheochromocytomas and Paragangliomas: 5 Years of Progress. Curr Oncol Rep. 2017; 19(12): 83

PubMed Abstract | Publisher Full Text

9. Niemeijer ND, Alblas G, van Hulsteijn LT, et al.: Chemotherapy with cyclophosphamide, vincristine and dacarbazine for malignant paraganglioma and pheochromocytoma: systematic review and meta-analysis. Clin Endocrino (Oxf). 2014; 81(5): 642-51. PubMed Abstract | Publisher Full Text

10. van Hulsteijn LT, Niemeijer ND, Dekkers OM, et al: ${ }^{131}$ I-MIBG therapy for malignant paraganglioma and phaeochromocytoma: systematic review and meta-analysis. Clin Endocrinol (Oxf). 2014; 80(4): 487-501. PubMed Abstract | Publisher Full Text

11. Ayala-Ramirez M, Feng L, Habra MA, et al:: Clinical benefits of systemic chemotherapy for patients with metastatic pheochromocytomas or sympathetic extra-adrenal paragangliomas: insights from the largest singleinstitutional experience. Cancer. 2012; 118(11): 2804-12. PubMed Abstract | Publisher Full Text | Free Full Text

12. Astuti $D$, Latif $F$, Dallol $A$, et al: Gene mutations in the succinate dehydrogenase subunit SDHB cause susceptibility to familial pheochromocytoma and to familial paraganglioma. Am J Hum Genet. 2001; 69(1): 49-54. PubMed Abstract | Publisher Full Text | Free Full Text

13. F Gimenez-Roqueplo A, Favier J, Rustin P, et al.: Mutations in the SDHB gene are associated with extra-adrenal and/or malignant phaeochromocytomas. Cancer Res. 2003; 63(17): 5615-21.

PubMed Abstract |F1000 Recommendation

14. Amar L, Baudin E, Burnichon N, et al.: Succinate dehydrogenase B gene mutations predict survival in patients with malignant pheochromocytomas or paragangliomas. J Clin Endocrinol Metab. 2007; 92(10): 3822-8. PubMed Abstract | Publisher Full Text

15. Pasini $B$, Stratakis CA: SDH mutations in tumorigenesis and inherited endocrine tumours: lesson from the phaeochromocytoma-paraganglioma syndromes. J Intern Med. 2009; 266(1): 19-42. PubMed Abstract | Publisher Full Text | Free Full Text

16. Dahia PL: Pheochromocytoma and paraganglioma pathogenesis: learning from genetic heterogeneity. Nat Rev Cancer. 2014; 14(2): 108-19. PubMed Abstract | Publisher Full Text

17. F Selak MA, Armour SM, MacKenzie ED, et al.: Succinate links TCA cycle dysfunction to oncogenesis by inhibiting HIF-alpha prolyl hydroxylase. Cancer Cell. 2005; 7(1): 77-85.

PubMed Abstract | Publisher Full Text | F1000 Recommendation

18. F Dahia PL, Ross $\mathrm{KN}$, Wright ME, et al.: A HIF1alpha regulatory loop links hypoxia and mitochondrial signals in pheochromocytomas. PLoS Genet. 2005; 1(1): $72-80$.

PubMed Abstract | Publisher Full Text | Free Full Text | F1000 Recommendation

19. F Favier J, Amar L, Gimenez-Roqueplo A: Paraganglioma and phaeochromocytoma: from genetics to personalized medicine. Nat Rev Endocrinol. 2015; 11(2): 101-11.

PubMed Abstract | Publisher Full Text | F1000 Recommendation
20. F Letouzé E, Martinelli C, Loriot C, et al:: SDH mutations establish a hypermethylator phenotype in paraganglioma. Cancer Cell. 2013; 23(6): 739-52. PubMed Abstract | Publisher Full Text | F1000 Recommendation

21. F Lepoutre-Lussey C, Thibault C, Buffet A, et al.: From Nf1 to Sdhb knockout: Successes and failures in the quest for animal models of pheochromocytoma. Mol Cell Endocrinol. 2016; 421: 40-8. PubMed Abstract | Publisher Full Text | F1000 Recommendation

22. F Lussey-Lepoutre C, Buffet A, Morin A, et al:: Rodent models of pheochromocytoma, parallels in rodent and human tumorigenesis. Cell Tissue Res. 2018; 372(2): 379-92.

PubMed Abstract | Publisher Full Text | F1000 Recommendation

23. Oh D, Kim T, Park YS, et al:: Phase 2 study of everolimus monotherapy in patients with nonfunctioning neuroendocrine tumors or pheochromocytomas/ paragangliomas. Cancer. 2012; 118(24): 6162-70. PubMed Abstract | Publisher Full Text

24. Park SR, Speranza G, Piekarz R, et al.: A multi-histology trial of fostamatinib in patients with advanced colorectal, non-small cell lung, head and neck, thyroid, and renal cell carcinomas, and pheochromocytomas. Cancer Chemother Pharmacol. 2013; 71(4): 981-90.

PubMed Abstract | Publisher Full Text | Free Full Text

25. F Roskoski R Jr: Vascular endothelial growth factor (VEGF) and VEGF receptor inhibitors in the treatment of renal cell carcinomas. Pharmacol Res. 2017; 120: 116-32.

PubMed Abstract | Publisher Full Text | F1000 Recommendation

26. McCormack PL: Pazopanib: a review of its use in the management of advanced renal cell carcinoma. Drugs. 2014; 74(10): 1111-25. PubMed Abstract | Publisher Full Text

27. F Al-Salama ZT, Keating GM: Cabozantinib: A Review in Advanced Renal Cell Carcinoma. Drugs. 2016; 76(18): 1771-8.

PubMed Abstract | Publisher Full Text | F1000 Recommendation

28. F Motzer RJ, Hutson TE, Tomczak $P$, et al:: Sunitinib versus interferon alfa in metastatic renal-cell carcinoma. N Engl J Med. 2007; 356(2): 115-24. PubMed Abstract | Publisher Full Text | F1000 Recommendation

29. Jimenez C, Cabanillas ME, Santarpia L, et al.: Use of the tyrosine kinase inhibitor sunitinib in a patient with von Hippel-Lindau disease: targeting angiogenic factors in pheochromocytoma and other von Hippel-Lindau disease-related tumors. J Clin Endocrinol Metab. 2009; 94(2): 386-91. PubMed Abstract | Publisher Full Text

30. Joshua AM, Ezzat S, Asa SL, et al:: Rationale and evidence for sunitinib in the treatment of malignant paraganglioma/pheochromocytoma. J Clin Endocrinol Metab. 2009; 94(1): 5-9. PubMed Abstract | Publisher Full Text

31. F Ayala-Ramirez M, Chougnet CN, Habra MA, et al:: Treatment with sunitinib for patients with progressive metastatic pheochromocytomas and sympathetic paragangliomas. J Clin Endocrinol Metab. 2012; 97(11): 4040-50. PubMed Abstract | Publisher Full Text | Free Full Text | F1000 Recommendation

32. F Motzer RJ, Hutson TE, Cella D, et al:: Pazopanib versus sunitinib in metastatic renal-cell carcinoma. N Engl J Med. 2013; 369(8): 722-31. PubMed Abstract | Publisher Full Text | F1000 Recommendation

33. Escudier B, Porta C, Bono P, et al.: Randomized, controlled, double-blind, crossover trial assessing treatment preference for pazopanib versus sunitinib in patients with metastatic renal cell carcinoma: PISCES Study. J Clin Oncol. 2014; 32(14): 1412-8. PubMed Abstract | Publisher Full Text

34. Jasim S, Suman VJ, Jimenez C, et al:: Phase II trial of pazopanib in advanced/ progressive malignant pheochromocytoma and paraganglioma. Endocrine. 2017; 57(2): 220-5. PubMed Abstract | Publisher Full Text

35. Keating GM: Axitinib: a review in advanced renal cell carcinoma. Drugs. 2015; 75(16): 1903-13.

PubMed Abstract | Publisher Full Text

36. $\mathrm{F}$ Wang $\mathrm{H}, \mathrm{Man} \mathrm{L}, \mathrm{Li}$ G, et al.: Comparative efficacy and safety of axitinib versus sorafenib in metastatic renal cell carcinoma: a systematic review and meta-analysis. Onco Targets Ther. 2016; 9: 3423-32. PubMed Abstract | Publisher Full Text | Free Full Text | F1000 Recommendation

37. Burotto Pichun ME, Edgerly $\mathrm{M}$, Velarde $\mathrm{M}$, et al:: Phase II clinical trial of axitinib in metastatic pheochromocytomas and paraganlgiomas (P/PG): Preliminary results. JCO. 2015; 33(7): 457. Publisher Full Text

38. Hoy SM: Cabozantinib: a review of its use in patients with medullary thyroid cancer. Drugs. 2014; 74(12): 1435-44. PubMed Abstract | Publisher Full Text

39. F Choueiri TK, Escudier B, Powles T, et al:: Cabozantinib versus Everolimus in Advanced Renal-Cell Carcinoma. N Engl J Med. 2015; 373(19): 1814-23. PubMed Abstract | Publisher Full Text | Free Full Text | F1000 Recommendation 
40. F Elisei R, Schlumberger MJ, Müller SP, et al.: Cabozantinib in progressive medullary thyroid cancer. J Clin Oncol. 2013; 31(29): 3639-46. PubMed Abstract | Publisher Full Text | Free Full Text | F1000 Recommendation

41. F Choueiri TK, Halabi S, Sanford BL, et al:: Cabozantinib Versus Sunitinib As Initial Targeted Therapy for Patients With Metastatic Renal Cell Carcinoma of Poor or Intermediate Risk: The Alliance A031203 CABOSUN Trial. J Clin Oncol. 2017; 35(6): 591-7.

PubMed Abstract | Publisher Full Text | Free Full Text | F1000 Recommendation

42. Jimenez C, Waguespack S, Habra MA, et al.: A Phase 2 Clinical Trial with Cabozantinib for Patients with Malignant Pheochromocytoma and Paraganglioma: Preliminary Results. The University of Texas MD Anderson Cancer Center, Oral Presentation, Global Academic Programs Symposium, Houston, Texas. 2017.

43. F Schlumberger M, Tahara M, Wirth LJ, et al.: Lenvatinib versus placebo in radioiodine-refractory thyroid cancer. N Engl J Med. 2015; 372(7): 621-30. PubMed Abstract | Publisher Full Text | F1000 Recommendation

44. F Schlumberger M, Jarzab B, Cabanillas ME, et al:: A Phase II Trial of the Multitargeted Tyrosine Kinase Inhibitor Lenvatinib (E7080) in Advanced Medullary Thyroid Cancer. Clin Cancer Res. 2016; 22(1): 44-53. PubMed Abstract | Publisher Full Text | F1000 Recommendation

45. Lenvatinib/everolimus improves survival better than everolimus alone in metastatic renal cell cancer. Clin Adv Hematol Oncol. 2015; 13(8): 512-3. PubMed Abstract

46. F Totzeck M, Mincu RI, Mrotzek S, et al.: Cardiovascular diseases in patients receiving small molecules with anti-vascular endothelial growth factor activity: A meta-analysis of approximately $\mathbf{2 9 , 0 0 0}$ cancer patients. Eur J Prev Cardiol. 2018; 25(5): 482-94.

PubMed Abstract | Publisher Full Text | F1000 Recommendation

47. F Gu YW, Poste J, Kunal M, et al:: Cardiovascular Manifestations of Pheochromocytoma. Cardiol Rev. 2017; 25(5): 215-22. PubMed Abstract | Publisher Full Text | F1000 Recommendation

48. Achari R, Hosmane B, Bonacci E, et al:: The relationship between terazosin dose and blood pressure response in hypertensive patients. J Clin Pharmacol. 2000; 40(10): 1166-72. PubMed Abstract

49. Prys-Roberts C, Farndon JR: Efficacy and safety of doxazosin for perioperative management of patients with pheochromocytoma. World J Surg. 2002; 26(8): 1037-42.

PubMed Abstract | Publisher Full Text

50. Plouin PF, Fitzgerald P, Rich T, et al:: Metastatic pheochromocytoma and paraganglioma: focus on therapeutics. Horm Metab Res. 2012; 44(5): 390-9. PubMed Abstract | Publisher Full Text

51. Roman-Gonzalez A, Zhou S, Ayala-Ramirez M, et al: Impact of Surgical Resection of the Primary Tumor on Overall Survival in Patients With Metastatic
Pheochromocytoma or Sympathetic Paraganglioma. Ann Surg. 2018; 268(1) 172-8

PubMed Abstract

52. F Li J, Gu J: Risk of gastrointestinal events with newly approved (after 2011) vascular endothelial growth factor receptor tyrosine kinase inhibitors in cancer patients: a meta-analysis of randomized controlled trials. Eur J Clin Pharmacol. 2017; 73(10): 1209-17.

PubMed Abstract | Publisher Full Text | F1000 Recommendation

53. Toledo RA: New HIF2 $\alpha$ inhibitors: potential implications as therapeutics for advanced pheochromocytomas and paragangliomas. Endocr Relat Cancer. 2017; 24(9): C9-C19.

PubMed Abstract | Publisher Full Tex

54. F Rathmell WK, Hickey MM, Bezman NA, et al.: In vitro and in vivo models analyzing von Hippel-Lindau disease-specific mutations. Cancer Res. 2004 64(23): 8595-603.

PubMed Abstract | Publisher Full Text | F1000 Recommendation

55. Favier J, Igaz $\mathrm{P}$, Burnichon $\mathrm{N}$, et al.: Rationale for anti-angiogenic therapy in pheochromocytoma and paraganglioma. Endocr Pathol. 2012; 23(1): 34-42. PubMed Abstract | Publisher Full Text

56. Toledo RA, Qin Y, Srikantan S, et al: In vivo and in vitro oncogenic effects of HIF2A mutations in pheochromocytomas and paragangliomas. Endocr Relat Cancer. 2013; 20(3): 349-59.

PubMed Abstract | Publisher Full Text | Free Full Text

57. F Chen W, Hill H, Christie A, et al.: Targeting renal cell carcinoma with a HIF-2 antagonist. Nature. 2016; 539(7627): 112-7.

PubMed Abstract | Publisher Full Text | Free Full Text | F1000 Recommendation

58. F Courtney KD, Infante JR, Lam ET, et al:: Phase I Dose-Escalation Trial of PT2385, a First-in-Class Hypoxia-Inducible Factor-2 $\alpha$ Antagonist in Patients With Previously Treated Advanced Clear Cell Renal Cell Carcinoma. J Clin Oncol. 2018; 36(9): 867-74

PubMed Abstract | Publisher Full Text | Free Full Text | F1000 Recommendation

59. Jimenez C, Chin BB, Noto RB, et al:: AZEDRA® (iobenguane l 131) in patients with metastatic and/or recurrent and/or unresectable pheochromocytoma or paraganglioma: Results of a multicenter, open-label, pivotal phase $2 \mathrm{~b}$ study. Paper presented at the NANETS, Philadelphia, Pennsylvania. 2017. Reference Source

60. F Strosberg J, El-Haddad G, Wolin E, et al:: Phase 3 Trial of ${ }^{177}$ Lu-Dotatate for Midgut Neuroendocrine Tumors. N Engl J Med. 2017; 376(2): 125-35. PubMed Abstract | Publisher Full Text | Free Full Text | F1000 Recommendation

61. Maurice JB, Troke R, Win Z, et al.: A comparison of the performance of ${ }^{68} \mathrm{Ga}$ DOTATATE PET/CT and ${ }^{123}$-MIBG SPECT in the diagnosis and follow-up of phaeochromocytoma and paraganglioma. Eur J Nucl Med Mol Imaging. 2012; 39(8): 1266-70.

PubMed Abstract | Publisher Full Text 


\section{Open Peer Review}

\section{Current Peer Review Status:}

\section{Editorial Note on the Review Process}

Faculty Reviews are review articles written by the prestigious Members of Faculty Opinions. The articles are commissioned and peer reviewed before publication to ensure that the final, published version is comprehensive and accessible. The reviewers who approved the final version are listed with their names and affiliations.

\section{The reviewers who approved this article are:}

\section{Version 1}

\section{David Taïeb}

1 Department of Nuclear Medicine, La Timone University Hospital, Marseille, France

2 European Center for Research in Medical Imaging, Aix-Marseille University, Marseille, France Competing Interests: No competing interests were disclosed.

2. Carmen C. Solórzano Division of Surgical Oncology and Endocrine Surgery, Vanderbilt University Medical Center, Nashville, Tennessee, USA

Competing Interests: No competing interests were disclosed.

\section{Judith Favier}

INSERM, UMR970, Paris-Centre de Recherche Cardiovasculaire, Paris, France

Competing Interests: No competing interests were disclosed.

The benefits of publishing with F1000Research:

- Your article is published within days, with no editorial bias

- You can publish traditional articles, null/negative results, case reports, data notes and more

- The peer review process is transparent and collaborative

- Your article is indexed in PubMed after passing peer review

- Dedicated customer support at every stage

For pre-submission enquiries, contact research@f1000.com 